\title{
A Study of Elizabethan Period (1558-1603)
}

\section{Muhammad Javed}

\author{
M.A. English Literature \\ Government College University
}

Faisalabad, Pakistan

dj211rb@gmail.com

\begin{abstract}
In this study, the researcher has mentioned the writers and their major works in Elizabethan age (1558-1603). The researcher has mentioned almost nineteen writers and their famous works. By reading this research paper, any general reader can easily understand that who are the major writers of the age and what are their famous works. The language and method of presenting the data are very easy. The researcher also has mentioned the major contributions of this era's writers. As we know that University Wits also fall in this era, thus the researcher has mentioned them and their works too. S. Dutta (2014) declared that The University Wits is a phrase used to title a group of late 16th-century English pamphleteers and playwrights who were studied at the universities Cambridge and Oxford. They appeared famous worldly writers. This era has reminisced for its richness of drama and poetry. This era ended in 1603. Elizabeth turns out to be one of the greatest prominent royals in English history, mainly after 1588, when the English beat the Spanish Armada which had been sent by Spain to reestablish Catholicism and defeat England. All the way through the Elizabethan age, English literature has changed from a shell into a delightful being with imagination,
\end{abstract}


creativeness, and boundless stories. It was not about mystery or miracle plays and the poetry was not nearby religion and the principles addressed in the Church.

Keywords: Elizabethan Age (1558-1603), Major Writers, Major Works, Contribution in Specific Genre, University Wits.

\section{Introduction}

In this study, the researcher has explored the writers and their major works in Elizabethan age (1558-1603). It is also declared that when the Elizabethan era began and who was the most famous. Monarch in English history. This era has reminisced for its richness of drama and poetry. This era ended in 1603. Elizabeth turns out to be one of the greatest prominent royals in English history, mainly after 1588, when the English beat the Spanish Armada, which had been sent by Spain to reestablish Catholicism and defeat England. Throughout the Elizabethan age, English literature has changed from a shell into a delightful being with imagination, creativeness, and boundless stories. The presenting order of the writers in the study is not because of their familiarity or famousness to the world but on birth-date. The writers who are discussed in this study are:

Philip Sidney (30 November 1554 - 17 October 1586)

Christopher Marlow or Kit Marlowe (26 February 1564 - 30 May 1593)

Walter Raleigh (1552 or 1554 - 29 October 1618)

William Shakespeare (26 April 1564 - 23 April 1616)

Thomas Campion (sometimes 12 February 1567 - 1 March 1620)

Edmund Spenser (1552 - 1599)

The University Wits (The researcher has mentioned seven character in this section) 
$>$ Francis Bacon $(1561$ - 1626)

Michael Drayton (1563 -1631)

John Lyly (1553 - 1606)

George Peele (July 25, 1556 - November 9, 1596)

$>$ Robert Greene (1558-1592)

$>$ Thomas Lodge $(1558-1625)$

$>$ Thomas Kyd $(1558-1594)$

John Marston (1576 - 1634)

$>$ Thomas Middleton (1580 - 1627)

$>$ Thomas Dekker $(1572-1632)$

$>$ John Day (1574 - 1638)

$>$ Beaumont (1584-1616) and Fletcher

It is also included in this research that which writer of the era got familiarity in the world on which literary work and who wrote first on any specific genres.

Literature review

The Elizabethan era began in 1558 when Elizabeth-first became queen. She was one of the most famous monarchs in English history. This era has reminisced for its richness of drama and poetry. This era ended in 1603.

Elizabeth one was a Protestant. She re-established the Church of England by means of the formal church in England. Everyone had to join their home-grown church and there were laws about the kind of religious facilities and the prayers which could be said, but Elizabeth did not inquire about people's actual beliefs. She flourished in getting stability between the opinions of Catholics and the more extreme Protestants. In this manner, she shunned any serious religious conflict in England. Elizabeth turned out to be one of the most famous royals in English history, chiefly after 1588, when the English overpowered the Spanish 
Armada, which had been sent by Spain to reestablish Catholicism and defeat England. There are a lot of writers of this age but the researcher mentioned well-known of them such as:

The Elizabethan Age has seen so exceedingly because of the contrasts with the eras before and after. It was a brief era of mostly internal peace between the English Reformation, with battles among Protestants and Catholics, and the fights amongst parliament and the monarchy that would engulf the seventeenth century. The protestant-catholic divide was established, for a time, by the Elizabethan Religious Settlement and parliament were still not tough enough to challenge royal absolutism.

Throughout the Elizabethan age, English literature has changed from a shell into a delightful being with imagination, creativeness, and boundless stories. It was not about mystery or miracle plays and the poetry was not nearby religion and the principles addressed in the

Church. the influence of personal beliefs or feelings, rather than facts increased and examining various features of life increased with the embellishment of plentiful authors. L. Arbaoui (2012) mentioned that Elizabethan literature placed a great basis for English literature and influenced hundreds and thousands of writers of the following literary eras. It is for this purpose, the Elizabethan period is known as the wonderful age of English literature.

Major writers of the age

1. Philip Sidney (30 November 1554 - 17 October 1586).

The Sir Philip Sidney was a soldier, scholar, English poet and courtier, who is known as one of the greatest prominent figures of the Elizabethan age.

The best of the Elizabethans, Sidney was effective in more than one genre of literature, but no one of his literary was published until after his passing away. His greatest achievement was his linked sequence of 108 love sonnets. These sonnets which be indebted much to Ronsard 
and Petrarch in style and tone, place Sidney as the supreme Elizabethan sonneteer excluding Shakespeare. Written to his mistress, Lady Penelope Rich, though dedicated to his wife, they disclose real lyric feeling expressed in a language delicately archaic. In form Sidney typically adopts the Petrarchan octave (ABBAABABA), with differences in the sestet which contain the English final couplet (a couple of successive lines of verse, usually rhyming and of the similar length)

Worthy works of Sir Philip Sidney

The Lady of May

The Lady of May' is a one-act play by the English Elizabethan poet Philip Sidney. The play, which pulls upon the literary custom of pastoral, is remarkable for its allegorical content concerning to Queen Elizabeth I, for whom the first creation was performed at the Earl of Leicester's country estate at Wanstead.

Astrophel and Stella

Astrophil and Stella (1580)' is an English sonnet order enclosing 108 sonnets and 11 songs. The title derives from the two Greek words, 'aster' and 'phil', and the Latin word 'stella' meaning star. Therefore Astrophil is the star lover, and Stella is his star.

The Countess of Pembroke's Arcadia

The Countess of Pembroke's Arcadia, also recognized simply as the Arcadia, is a lengthy prose pastoral romance written in the direction of the end of the sixteenth century. Having completed one version of his text, Sidney later meaningfully lengthened and revised his work. 
An Apology for Poetry

An Apology for Poetry' is a work of literary criticism. It was written in around 1580 and first published in 1595, after his passing away.

The Sidney Psalms

Sidneian Psalms' or The Sidney Psalms' was a sixteenth century translation into English of the Psalms. It was the great work of Mary Sidney and Philip, aristocratic siblings who were greatly influential Elizabethan writers.

2. Christopher Marlow or Kit Marlowe (26 February 1564 - 30 May 1593)

L. Erne (2005) argued that Christopher Marlowe, was an English poet, translator and playwright of the Elizabethan age. He was the prime Elizabethan tragedian of his era. He significantly exerts influence on William Shakespeare, who was born in the same year as Marlowe and who moved to develop the greatest Elizabethan playwright after Marlowe's enigmatic early death. Marlowe's plays are famous for the usage of blank verse and their get the better of protagonists.

L. Erne (2005) argued that some scholars and researchers have faith in that a warrant was allotted for Marlowe's arrest on 18 May 1593. There was no given reason for it, however, it was supposed to be associated with claims of blasphemy a manuscript supposed to have been written by Marlowe was said to encompass "vile heretical conceipts". On 20 May, he was carried to the court to be present upon the Privy Council for questioning. There is no record of their having met that day and he was ordered to be present upon them each day afterwards until "licensed to the contrary". The ten days late, he was stabbed to passing away by Ingram Frizer. Whether or not the stabbing was associated to his arrest leftovers unidentified Major Contribution to Literature He was father of English Drama 
Worthy works

Dido, Queen of Carthage

Dido, Queen of Carthage (1586) is a small play written by the English writer Christopher Marlowe, with thinkable aids by Thomas Nashe. The story of the play emphases on the classical figure of Dido, the Queen of Carthage.

Tamburlaine, part one, part two (1587-1588)

Tamburlaine the Great is a play in two parts. It is lightly constructed on the life of the Central Asian emperor.

The Jew of Malta (1589)

The Jew of Malta is a play written in 1589 . The plot mainly circles around a Maltese Jewish merchant called Barabas

Doctor Faustus (1589 or1593)

The Tragical History of the Life and Death of Doctor Faustus, usually mentioned to just as Doctor Faustus, is an Elizabethan tragedy, based on German stories about the title and major character Faust.

Edward II (1592)

Edward II is a play written by Marlowe. It is one of the primary English history plays. The name of the first publication is "The Troublesome Reign and Lamentable Death of Edward the Second, King of England, with the Tragical Fall of Proud Mortimer" The Massacre at Paris (1593)

The Massacre at Paris is an Elizabethan play by the English dramatist Christopher Marlowe and a Restoration drama by Nathaniel Lee, the latter chiefly think of for a song by Henry Purcell Hero and Leander (1598) 
The poem was incomplete because of the unexpected death of Marlowe. George Chapman finished the work. It is originally published in 1598.

3. Walter Raleigh (1552 or $1554-29$ October 1618)

Walter Raleigh was an English wealthy man, poet, writer, courtier, spy, soldier, politician and explorer. He is also well recognized for spreading tobacco in England. Raleigh was one of the most famous figures of the Elizabethan age.

Major Works

The Walter Raleigh is the writer of books such as Remains of Sir Walter Raleigh and mentioned his main works in their book.

Poems by Ralegh

All done, and some unfinished, poems written by Ralegh or reasonably qualified to him:

"Lines from Catullus"

> "The Advice"

"Another of the Same"

"Love and Time"

$>$ "Conceit begotten by the Eyes"

"Epitaph on Sir Philip Sidney"

$>$ "Even such is Time"

$>$ "The Excuse"

$>$ "Farewell to the Court"

> "His Petition to Queen Anne of Denmark"

"If Cynthia be a Queen"

> "In Commendation of George Gascoigne's Steel Glass"

"The Lie" 
> "Like Hermit Poor"

$>$ "Epitaph on the Earl of Leicester"

"False Love"

4. William Shakespeare (26 April 1564 - 23 April 1616)

The William Shakespeare was an English poet, playwright, and actor, usually regarded as the highest writer in the English language and the world's supreme dramatist. He is frequently called England's nationwide poet and the "Bard of Avon" His present works, containing collaborations, contain some 39 plays, 154 sonnets, two long narrative poems, and a little other verses, some of the uncertain authorship. His plays have been translated into each main living language and are performed further often than those of any other playwright.

Worthy works

In the "The Complete Works of William Shakespeare" the editor mentioned his almost all work. But the researcher mentioned some of his works here in his study. Hamlet

The play is set in Denmark and keep an eye on the prince Hamlet, who seeks revenge upon his uncle Claudius. Claudius killed his brother, Hamlet's father, with the purpose of seizing the throne and also wed his wife and Hamlet's mother Gertrude (Page 420, The Complete Works of William Shakespeare).

King Lear

King Lear is a tragedy written by William Shakespeare. It tells the story of a king who gives his power and land to two of his three daughters, after they declare their love for him in an extremely fawning and obsequious manner (page 1048, The Complete Works of William Shakespeare).

Henry IV 
Henry four Part one is the tale of rebellion, power and honor. Richard is passed away and Henry Bolingbroke is now Ruler Henry IV. The king is not taking delight and pleasure his rule. He feels remorseful regarding the removal of Richard and it worries his conscience. It is thought to have been written no later than 1597 (page 555, The Complete Works of William Shakespeare).

Othello

The Tragedy of Othello of the Moor of Venice is a tragedy composed in around 1603 and first printed in 1565 . One of Shakespeare's most firmly woven works, it discovers themes of forgiveness, revenge, love, betrayal and racism and has laid multiple operatic, film, and literary adaptations (page 1475, The Complete Works of William Shakespeare) Richard III

Richard III is a historical, believed to have been composed approximately 1593 . It portrays the Machiavellian growth to power and following short rule of King Richard III of England. The play is grouped amongst the histories in the First Folio and is most often classified (page 1604, The Complete Works of William Shakespeare)

\section{A Midsummer Night's Dream}

It is a comedy composed in $1595 / 96$. It depicts the events near the wedding of Theseus, the Duke of Athens, to Hippolyta (page 1388, The Complete Works of William Shakespeare)

5. Thomas Campion (sometimes 12 February 1567 - 1 March 1620)

M. B. Bryan (1974) He was an English poet, composer and physician. He composed above a hundred lute songs, masques for dancing, and a commanding technical treatise on music. Major works 
Poem

$>$ Come Quickly!

Now Winter Nights Enlarge

There Is A Garden In Her Face

A Hymn In Praise Of Neptune

$>$ Cherry-Ripe

$>$ Integer Vitae

Thrice Toss These Oaken Ashes

6. Edmund Spenser $(1552-1599)$

The entrance of Edmund Spencer through The Shepherd's Calendar noticeable the start of a new age in English poetry. He formed poetry that could touch every single feature of interest and life.

Worthy works

The Shepherd's Calendar

It is the first main poetic work, published in 1579. It describes with each month of the year in the form of pastoral poems.

The Epithalamion

It is an ode composed to his bride, Elizabeth Boyle, on their bridal day in 1594. It was first published in 1595 in London by William Ponsonby as part of a volume titled Amoretti and Epithalamion. However, it consists of great imagination and rhythm making it suitable for the reader.

Astrophel

He has composed eighty-nine sonnets below the title Amoretti and dedicated an elegy titled Astrophel for the death of his dear friend, Philip Sidney. 
The Faery Queen

It is an epic poem. The Books I-III were first printed in 1590, and then reprinted in 1596 together with books IV-VI. His stanza is still in usage and this is led to English literature through his most distinguished work The Faery Queen. The rhyme scheme of Spenserian stanza is aba bbc bcc. His contributions made him the poet's poet of English poetry.

\section{The University Wits}

S. Dutta (2014) declared that The University Wits is a phrase used to title a group of late 16th-century English pamphleteers and playwrights who were studied at the universities Cambridge and Oxford. They appeared famous worldly writers. S. Dutta (2014) mentioned their names are being given below:

$>$ John Lyly 1554-1606

Thomas Kyd 1557-1586

George Peele 1558-1597

Thomas Lodge 1558-1625

Robert Greene 1560-1592

Christopher Marlowe 1564-1593

Thomas Nash 1567-1601

Elizabethan literature would have been imperfect and incomplete lacking the contributions made by the above-stated group of writers who educated to Cambridge and at Oxford University.

8. Francis Bacon $(1561-1626)$

Bacon is a fount of knowledge who worked on jury, philosophy, literature, oration, science, etc. He is considered the father of empiricism. Throughout his era, he has served in 
great standing positions like Attorney General and Lord Chancellor. He always addressed the significance of science over religion.

His work in one way of the new about the systems in the requirement of change and society. However, his highest achievements are his Essays that are fifty-eight in quantity. It's every essay is a masterwork imitating human knowledge and how man worries everything. The Advancement of Learning The Advancement of Learning' introduced the scientific technique throughout the Scientific Revolution, had a deep influence on empirical philosophy. It is originally published in 1605. The Novum Organum

It is contained of three major steps: first, an explanation of facts; second, an arrangement, or organization, of those facts into three categories, examples of the existence of the characteristic below investigation, examples of its nonexistence, or examples of its presence in variable degrees; third, the refusal of whatever looks, in the light of these tables, not to be linked with the phenomenon under examination and the determination of what is associated with it. It is originally published 1620

The New Atlantis

New Atlantis is a partial utopian novel. It is published after Bacon's death in 1626. It seemed tucked and unheralded into the back of a lengthier work of natural history, Sylva sylvarum.

\section{Michael Drayton (1563-1631)}

Michael Drayton was remarkable with versatility and he was gifted to enter into every side of poetry with easiness. He started his life in writing with a holy work titled Harmony of the Church. It was a little of a disappointment and he comes back with a pastoral verse 
titled Shepherd's Garland. After that, he penned on patriotism through Polyolbion. It extended him countless attention and clapping while his masterwork was yet to come. Major works

Polyolbion

The Poly-Olbion is a geographical poem labelling Wales and England. It is originally published in 1612, it was republished with a second part in 1622. Drayton had been employed on the project since at least 1598 .

Ballad of Agincourt

His Ballad of Agincourt labels about the fight fought at Agincourt while the Hundred Years War. It has pleasing features unique to the Elizabethan era.

Rest writers of the age and their contributions to English Literature

10. John Lyly (1553 - 1606)

John Lyly was an English dramatist, poet, courtier, writer, and best known during his lifetime for his best-remembered plays. Lyly's affected literary style, creating in his first books, is known as euphuism.

Worthy works

Eupheus

Euphues: The Anatomy of Wit, a moral romance. It was originally published in 1575 . It was followed by Euphues and his England.

Endimion

Endymion, the Man in the Moon is an Elizabethan period comedy. It is composed approximately in 1588. The action of the play revolves around a young courtier, Endymion, 
who is sent into a never-ending rest by Tellus, his former lover, for the reason that he has rejected her to worship the ageless Queen Cynthia. It is originally published in 1588 .

Mother Bombie

It is a stage comedy play. It is distinctive in Lyly's dramatic canon as a work of farce and social realism; in Mother Bombie alone, Lyly departs from his dream.

The Woman in the Moon

The Woman in the Moon is stage comedy play, its distinctive position in that it is the only play Lyly penned in blank verse rather than prose. It has presented critics and scholars with a variety of problems and questions.

Major contribution to Literature

Euphuism, a literary prose style began because of John Lyly's work - Eupheus.

11. George Peele (July 25, 1556 - November 9, 1596)

George Peele was an English poet, dramatist and translator who is greatest well-known for his supposed but not universally believed collaboration with Shakespeare on the play Titus Andronicus.

Worthy works

The Arraignment of Paris

It is a rustic entertainment, planned to compliment Elizabeth. Greene's specialty was comical histories, interweaving a thoughtful plot set amongst monarchs with comic action connecting clowns. It is originally published 1584

Old Wives' Tale

It is a play firstly printed in England in 1595 . The play has been recognized as the first English work to satirize the romantic dramas famous at the time. 


\section{Robert Greene (1558-1592)}

It was an English writer famous in his day, and now preeminent for a posthumous pamphlet credited to him, Greene's Groats-Worth of Witte, bought with a million of Repentance, generally thought to contain an attack on Shakespeare.

Worthy works

$>$ A Groatsworth of Wit

The Honourable History of Friar Bacon and Friar Bungay

George a green, or The Pinner of Wakefield

Orlando Furioso

Looking Glass for London and England

Major contribution to Literature

Robert Greene is said to have written his plays in the form of "Romantic Comedy". The first English writer to do so.

13. Thomas Lodge $(1558-1625)$

Thomas Lodge was an author during the Elizabethan and Jacobean eras and English physician.

Worthy works

Rosalynde

The Wounds of Civil War

Major Contribution to Literature

Rosalynde is considered as a source for Shakespeare's As You Like It.

Thomas Nashe (November 1567 - 1601) 
Thomas Nashe was a poet, playwright, satirist and an important pamphleteer. He is identified for his novel The Unfortunate Traveller, his pamphlets with Pierce Penniless, and his many defenses of the Church of England.

Worthy works

Summer's Last Will and Testament

The Isle of Dogs

The Unfortunate Traveller, or the Life of Jack Wilton

The Anatomy of Absurdity

\section{Lenten Stuffe}

Pierce Penniless

Major Contribution to Literature

Life of Jack Wilton is known as the first English historical novel.

\section{Thomas Kyd (1558-1594)}

Thomas Kyd was an English playwright, the writer of The Spanish Tragedy, and one of the utmost significant figures in the progress of Elizabethan drama.

Worthy works

The Spanish Tragedy

Ur Hamlet

$>$ Cornelia

$>$ Jeronimo

Major Contribution to Literature

Founder of the genre Romantic Tragedy. 


\section{John Marston (1576 - 1634)}

He was an English playwright, poet and satirist during the late Elizabethan and early Jacobean eras. His career as an author continued a decade, and his work is remembered for its active and often incomprehensible style, its contributions to the progress of a distinctively Jacobean style in poetry, and its idiosyncratic terminology.

Worthy Works

- Antonio and Mellida

- Antonio's Revenge

- The Malcontent

- The Scourge of Villany

Major Contribution to Literature

Marston is identified for his violent melodramatic tragedies.

16. Thomas Middleton (1580 - 1627)

He has written mostly throughout the Jacobean age than the Elizabethan period Worthy Works

A Game at Chess

Women Beware Women

The Changeling

A mad world, my Masters 
17. Thomas Dekker (1572 - 1632)

Thomas Dekker was an English dramatist and pamphleteer, a multipurpose and productive author, whose career covered several decades and brought him into interaction with many of the era's most well-known dramatists.

Worthy Works

The Honest Whore

The Shoe-Maker's Holiday

18. John Day (1574 - 1638)

He was an English dramatist of the Elizabethan and Jacobean eras.

Worthy Works

The Parliament of Bees

The Isle of Gulls

Humour out of Breath

Law Tricks

19. Beaumont (1584 -1616) and Fletcher (1579 - 1625)

Maid's Tragedy

The Knight of the Burning Pestle

They are called as twin souls of the drama.

Methodology

The major focus of the Methodology is to describe the major writers and their work of Elizabethan age.

Research questions 
Who are the most important writers of the Elizabethan age (1558-1603) and their major works?

Objectives

The researcher most important objective is to explore the writers and great works of Elizabethan age.

Data collection

The researcher has collected the data from different researches and books of the contemporary, the reference of the books and researches are given in the reference section of the research.

Findings

In order to prove the research question the researcher has mentioned the almost nineteen writers and their works of the Elizabethan age. By reading this research paper, any general reader can easily understand that who are the major writers of the age and what are their famous works.

\section{Discussion and Conclusion}

The major purpose of this study is to show the major writers and their works in Elizabethan age which are delightfully described in the paper. The language and method of presenting the data is very easy therefore the research is meekly saying that any general reader can get the major idea of the age with one reading. 


\section{References}

L. Arbaoui (2012). The concise history of English literature, the Elizabethan Period.

Erne, L. (2005). Biography, Mythography, and Criticism: The Life and Works of Christopher Marlowe.

The Complete Works of William Shakespeare, Shakespeare is copyright 1990-1993 by World Library INC.

Bryan, M. B. (1974) Recent Studies in Campion.

Dutta, S. (2014) The University Wits: Their Contribution to English Drama 